\title{
ALIH KODE DAN CAMPUR KODE DALAM NOVEL SABTU BERSAMA BAPAK KARYA ADHITYA MULYA
}

\author{
Ika Fibri Fitriana \\ SMP Taruna Jaya 1 Surabaya \\ ikafibri.pbsi@gmail.com
}

\begin{abstract}
ABSTRAK
Penelitian ini menelaah wujud alih kode dan campur kode dalam novel Sabtu Bersama Bapak (SBB) karya Adhitya Mulya. Tujuannya untuk mendeskripsikan wujud alih kode dan campur kode teks dalam novel $S B B$. Hasil penelitian menunjukkan bahwa terdapat wujud alih kode berupa : a) Alih bahasa Sunda ke bahasa Indonesia, b) Alih bahasa Indonesia ke bahasa Jawa, c) Alih bahasa Indonesia ke bahasa Inggris, dan d) Alih bahasa Inggris ke bahasa Indonesia. Faktor yang melatarbelakangi terjadinya alih kode yang terdapat dalam novel yaitu, a) Pembicara atau penutur, b) Lawan tutur, c) Perubahan topik pembicaraan, dan d) Pokok pembicaraan. Selain alih kode terdapat pula wujud campur kode yang berupa : a) Penyisipan unsur yang berwujud kata, b) Penyisipan unsur yang berwujud frasa, c) Penyisipan unsur yang berwujud pengulangan kata, dan d) Penyisipan unsur yang berwujud klausa. Faktor yang melatarbelakangi terjadinya campur kode dalam novel SBB yaitu, a) Identifikasi peranan, b) Identifikasi ragam, dan c) Keinginan untuk menjelaskan.
\end{abstract}

Kata kunci: Alih Kode dan Campur Kode.

\begin{abstract}
This study the existence of code switching and code mixing contained in the novel Sabtu Bersama Bapak ( $S B B$ ) by Adhitya Mulya. The purpose of was to describe the form of code switching and code mixing seen from the sentences contained in the text of novel $S B B$. Data collection this study used documentation, reading, recording, classification and literature techniques. The conclusions of the research results show that there is a form of code switching in the form of: a) Switching Sundanese to Indonesian, b) Switching Indonesian to Javanese, c) Switching Indonesian to English, and d) Switching English to Indonesian. Factors behind the occurrence of code switching contained in the novel namely, a) Speakers, b) Opposition of speech, c) Changes to the topic of conversation, and d) Topic of conversation. Beside code switching, there is also a code mixing in the form of: a) Insertion of elements in the form words, b) Insertion of elements in the form of phrases, c) Insertion of elements in the form of word repetition, and d) Insertion of elements in the form of clauses. The underlying factor of the occurrence of code mixing in the novel is, a) Identification of roles, b) Identification of variety, and c) Desire to explain.
\end{abstract}

Keywords: Code switching and Code Mixing 


\section{PENDAHULUAN}

Bahasa merupakan suatu sistem tanda bunyi ujaran yang bersifat arbitrer. Bahasa mempunyai kaidah yang sama, namun karena masyarakat yang memiliki latar belakang dan kebiasaan yang berbeda, bahasa menjadi beragam. Keragaman bahasa di masyarakat inilah yang menjadikan adanya wujud alih kode dan campur kode. Fakta di masyarakat berkenaan dengan alih kode dan campur kode membuktikan bahwa keberagaman bahasa dapat terjadi dalam proses interaksi sosial antarmasyarakat. Berdasarkan hasil observasi, wujud alih kode dan campur kode ternyata dapat pula terjadi dalam dunia sastra. Salah satu karya sastra yang banyak diwarnai keberagaman bahasa adalah novel Sabtu Bersama Bapak karya Adhitya Mulya.

Fakta yang ditemukan dalam novel tersebut bahasa yang digunakan yakni, bahasa Indonesia, Jawa, Sunda, dan Inggris. Novel tersebut menghadirkan wujud alih kode dan campur kode yang terjadi secara spontan untuk mengganti kode bahasa dalam proses komunikasi. Penulis yang menghadirkan unsur alih kode dan campur kode dalam novel Sabtu Bersama Bapak tentu memiliki maksud untuk memperkuat ide cerita dan menggambarkan kehidupan tokoh secara lebih nyata.

Adanya gejala alih kode dan campur kode dalam novel tersebut dapat memperluas pengetahuan dan wawasan. Kecenderungan alih kode dan campur kode pada bentuk sastra ini dilatarbelakangi oleh kondisi sosial dan latar belakang tokoh yang mengakibatkan penggunaan bahasa Jawa, bahasa Sunda, dan bahasa Inggris dalam setiap komunikasinya. Wujud alih kode dan campur kode tersebut memudahkan masyarakat untuk saling berkomunikasi walaupun memiliki latar belakang yang berbeda.

Tujuan penelitian ini adalah: (1) Untuk mendeskripsikan wujud alih kode dan fartor penyebab alih kode yang terdapat dalam novel Sabtu Bersama Bapak karya Adhitya Mulya; (2) Untuk mendeskripsikan wujud campur kode dan faktor penyebab campur kode yang terdapat dalam novel Sabtu Bersama Bapak karya Adhitya Mulya.

\section{METODE PENELITAIN}

Jenis penelitian yang digunakan dalam penelitian ini adalah deskriptif kualitatif yaitu penelitian yang dinyatakan dalam keadaan yang sewajarnya yang tidak diubah dalam bentuk angka. Data dalam penelitian ini berupa teks dalam novel SBB karya 
Adhitya Mulya. Data di analisis untuk mengidentifikasi dan mengklasifikasi wujud alih kode dan campur kode yang ada dalam novel tersebut. Mahsun (2006: 233) menyebutkan bahwa analisis kualitatif lebih fokus untuk menunjukan makna, deskripsi, dan penempatan data dalam bentuk kata-kata. Teknik analisis data yang digunakan dalam penelitian ini adalah analisis dokumen.

Objek dalam penelitian adalah kata, kalimat yang memiliki wujud peralihan dan percampuran kode pada setiap teks dalam novel $S B B$ karya Adhitya Mulya. Teknik pengumpulan data dilakukan dengan membaca novel secara intensif, mencatat halaman yang terdapat teks alih kode dan campur kode, dan mengklasifikasikan data. Terdapat tiga teknik untuk menganalisis data menurut Milles dan Huberman (dalam Sugiyono, 2014: 246-252) dalam penelitian ini yaitu, reduksi data, penyajian data, penarikan simpulan.

\section{PEMBAHASAN}

Indonesia merupakan masyarakat multilingual. Masyarakat tersebut tidak hanya menguasai satu bahasa untuk berkomunikasi. Masyarakat yang multilingual tersebut tidak menutup kemungkinan untuk melakukan alih kode dan campur kode pada saat berkomunikasi. Alih kode dan campur kode tidak hanya terjadi dalam interaksi secara langsung, namun dapat terjadi pula dalam bentuk teks atau tulisan seperti dalam novel Sabtu Bersama Bapak (SBB). Hymes (dalam Chaer dan Agustina, 2010:107) yang menyebutkan bahwa alih kode tidak hanya terjadi antar bahasa melainkan dapat terjadi antar ragam atau gaya bahasa. Berbeda dengan pendapat Hymes, Kridalaksana (2001) yang berpendapat bahwa campur kode adalah penggunaan satu bahasa ke bahasa lain untuk memperluas gaya bahasa yang berupa kata, frasa, dan klausa. Suwito (dalam Aslinda dan Syafyahya, 2007:86) menyebutkan terdapat dua wujud alih kode yaitu alih kode internal dan alih kode eksternal.

\section{Wujud Alih Kode Internal dalam Novel $S B B$}

Alih kode internal (internal code switching) adalah peralihan pemakaian bahasa yang terjadi antardialek, antarragam, atau antargaya dalam lingkup satu bahasa.

a. Alih Bahasa Sunda ke Bahasa Indonesia 
Setting : Dialog antara Ibu Itje dan Ibu Tyas terjadi melalui telepon. Ibu Itje dan Ibu Tyas adalah seorang Ibu rumah tangga.

Ibu Itje : Mampir atuh ke rumah.

Ibu Tyas : Tur nuwun, Ceu. Tapi lagi repot ki ngasuh cucu.

Ibu Itje : Bawa cucu dari Jakarta?

Ibu Tyas : Hehe, mau tak pamerken di nikahan Ceu Asep nanti. Aku bawa cucu dan anak keduaku.

Ibu Itje : Oh, Retna udah menikah?

Ibu Tyas : Belum, Ceu. Bukan, ini cucu dari si Mas. Ceritanya panjang Ceu Itje datang, kan?

(SBB/BSKBI/32)

Tuturan kalimat di atas terdapat wujud alih kode dari bahasa Sunda ke bahasa Indonesia. Wujud alih kode tersebut dilakukan oleh Ibu Tyas yang pada awal percakapnnya dengan Ibu Itje menggunakan bahasa Sunda dalam tuturannya "Tur nuhun, Ceu. Tapi lagi repot ki ngasuh cucu." Dalam tuturan tersebut Ibu Tyas menggunakan bahasa Jawa dalam tuturannya yang dalam bahasa Indonesia berarti “Terimakasih Mbak. Tapi lagi sibuk ini mengurus cucu.” Pada tuturan beriktnya Ibu Tyas menggunakan bahasa Indonesia dalam tuturan "Belum, Ceu. Bukan, ini cucu dari si Mas. Ceritanya panjang Ceu Itje datang, kan?”. Wujud alih kode yang dilakukan oleh Ibu Tyas ini karena sudah adanya keakraban yang dijalain oleh keduanya dan didukung dengan situasi yang santai pada saat berkomunikasi.

b. Alih Bahasa Indonesia ke Bahasa Jawa

Setting : Dialog ini terjadi antara tokoh Bambang, Firman, dan Wati yang terjadi melalui pesan e-mail di kantor. Bambang, Firman, dan Wati adalah seorang seles yang bekerja di perusahaan perbankkan.

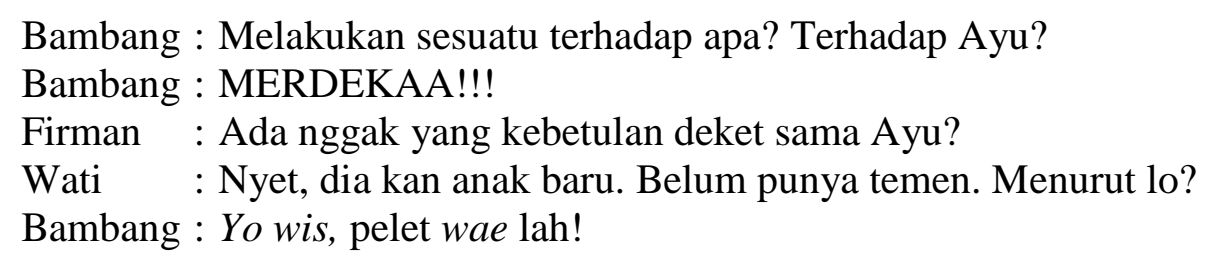

Dialog yang terjadi dalam pesan e-mail untuk membicarakan Ayu, seorang pegawai baru di Banking asing tempat mereka bekerja. Dialog tersebut dilakukan oleh tokoh Bambang, Firman, dan Wati. Terdapat wujud alih kode dalam dialog 
yang dilakukan oleh Bambang. Pada awal tuturannya Bambang menggunakan bahasa Indonesia untuk menyampaikan pesannya pada rekan-rekannya. Tuturan selanjutnya Bambang menggunakan bahasa Jawa pada tuturan "Yo wis, pelet wae lah!" yang dalam bahasa Indonesia yaitu "Ya sudah, pelet saja lah." Alih kode yang dilakukun oleh Bambang tersebut merupakan ungkapan untuk memikat Ayu yang akan dijodohkan untuk direkturnya tersebut. Alih kode tersebut terjadi karena sudah adanya hubungan keakraban antar tokoh.

\section{Wujud Alih Kode Eksternal dalam Novel SBB}

Alih kode eksternal (external code switching) adalah peralihan pemakaian bahasa dari satu bahasa ke bahasa lain.

a. Alih Bahasa Indonesia ke Bahasa Inggris

Setting : Percakapan antara tokoh Claus dan Cisse ini terjadi di lorong perusahaan kilang minyak di Jerman. Clause dan Cisse adalah seorang masinis.

Claus : Sudah akui saja! Kamu lupa!

Cisse : Saya tidak lupa! Saya tutup dengan baik!

Claus : Oh, jadi kamu kira angin yang membukanya kembali?

Cisse : Bisa jadi!

Claus : Kamu engineer bodoh!

Cisse : That's it! I quit!!

Claus : Haha, silahkan! Quitter!

(SBB/BIKBIG/58)

Percakapan di atas merupakan dialog yang dilakukan antara tokoh Claus dan Cisse pada saat berada di lorong ruang IT. Wujud alih kode dilakukan oleh Cisse yang pada awal percakapn menggunakan bahasa Indonesia kemudia beralih menggunakan bahasa Inggris “That's it! I quit!!” yang artinya "Itu adalah! Aku berhenti!". Tuturan yang dilakukan oleh Cisse merupakan wujud alih kode eksternal yang berupa peralihan pemakaian bahasa dari bahasa Indonesia beralih ke bahasa Inggris. Peralihan yang dilakukan oleh Cisse dengan maksud ingin menegaskan bahwa Ia memang tidak bersalah dan memilih untu berhenti agar permasalahan tersebut tidak semakin panjang.

Faktor Penyebab Terjadinya Alih Kode dalam Novel SBB 
a. Pembicara atau penutur

Pembicara atau penutur merupakan orang yang berperan penting dalam menentukan bentuk tuturan yang disampaikan dalam berkomunikasi.

Setting : Percakapan antara tokoh Gunther dan Cakra di ruang kerja Gunther. Gunther adalah seorang Divisi directo sedangkan Cakra adalah Deputy director.

Gunther : Saya ingin kamu pergi ke Makassar. Bantu kepala cabang sana untuk bangun tim micro finance yang solid. Kamu tidak terlihat semangat.

Cakra : Apakah bisa kita kirim orang lain?

Gunther: You're the best one we have.

Cakra : Satu bulan, ya, Gunther.Saya berpikir, membangun tim bukan pekerjaan yang mudah. Satu bulan. Saya akan bangun tim di sana Gunther : Deal. satu bulan atau sampai selesai. Setelah selesai, saya balik, ya.

(SBB/PAP/138)

Kutipan dialog di atas merupakan contoh dialog yang termasuk ke dalam faktor penyebab terjadinya alih kode dalam bentuk pembicara atau penutur. Dialog yang terjadi antara Gunther dan Cakra membicarakan program barunya yang akan membangun cabang perusahaan di Makassar. Wujud faktor penyebab alih kode dari penutur terlihat pada tuturan Gunther sebagai penutur yang meminta bantuan kepada Cakra sebagai lawan tuturnya pada tuturan.

b. Lawan tutur atau pendengar

Seorang lawan tutur atau pendengar yaitu seorang yang berusaha mengimbangi kemampuan berbahasa dari penutur.

Setting : Dialog yang terjadi antara tokoh Cakra, Firman, dan Wati ini terjadi di sebuah Mall di Jakarta.

Cakra : Sebenarnya kalian gak bisa nyalahin penampilan saya. Kalian semua tahu kenapa kita dress down seperti ini.

Firman : Tapi ya, Bapak kan Deputy Director, Pak. Kayaknya udah gak level deh untuk Bapak ikut blusukan sama kita. But that's where the action is! And yet that's where you no longer belong, Pak. Dulu saat Bapak masih jadi National sales manager, iya. Tapi Bapak udah DD sekarang, itu gak main-main.

Wati : Canggih juga bahasa Inggris lu, Man. Naksir nih gue, kayaknya rada dikit. 
$(\mathrm{SBB} / \mathrm{LTAP} / 116)$

Cakra dan Firman adalah tokoh yang melakukan faktor penyebab alih kode penyebab alih kode seabagi lawan tutur atau pendengar. Firman beralih kode dari bahasa Indonesia ke bahasa Inggris untuk mengimbangi menjelaskan pernyataan Cakra mengenai "dress down" atau cara berpakain Cakra. Terlihat pada tuturan Firman “Tapi ya, Bapak kan Deputy Director, Pak. Kayaknya udah gak level deh untuk Bapak ikut blusukan sama kita. But that's where the action is! And yet that's where you no longer belong, Pak. Dulu saat Bapak masih jadi National sales manager, iya. Tapi Bapak udah DD sekarang, itu gak main-main.” Faktor penyebab alih kode yang berupa lawan tutur ini dianggap sebagai alih varian karena penutur dan mitra tutur memiliki latar belakang bahasa yang sama.

c. Perubahan topik pembicaraan

Berubahnya topik pembicaraan dapat juga menyebabkan terjadinya alih kode. Berubahnya topik pembicaraan yang dimaksud yaitu perpindahan topik pembicaraan yang terjadi antara penutur dan lawan tutur saat berkomunikasi.

Setting : Dialog ini terjadi di ruang kantor tempat mereka bekerja yang terjadi pada tokoh Rizki, Cakra, Wati, dan Firman.

Rizki : Bapak ganteng hari ini.

Cakra : Thanks. Saya gak notice sebelumnya.

Wati : Hati-hati kepentok,, Riz,.Tuh kan bener.

Firman : Udah ada yang kepelintir Pak, kepalanya.

Cakra : Ah, masih anak kecil.

Firman : Lumayan kece, Pak.

Cakra : Guys, do I look like a million dollar man?

Wati : Nope. But you look good.

Firman : You look like Cakra.

(SBB/ PTP/121)

Faktor penyebab alih kode berupa perubahan topik pembicaraan yang terjadi antara Rizki, Cakra, Firman, dan Wati. Wujud perubahan topik pembicaraan tersebut dilakukan oleh tokoh Cakra. Pokok pembicaraan yang dibahas adalah mengenai perempuan magang yang bernama Rizki yang mengagumi Cakra. 
d. Pokok pembicaraan

Pokok pembicaraan atau pokok bahasan adalah masalah apa yang akan dibahas sebagai topik yang akan dibicarakan antara penutur dan mitra tutur.

Setting : Percakapan antara Cakra, Firman, dan Wati ini terjadi di sebuah Mall di Jakarta. Cakra adalah seorang deputy derector sedangkan Firman dan Wati adalah seorang seles atau bawahan Cakra.

Cakra : Sebenarnya kalian gak bisa nyalahin penampilan saya. Kalian semua tahu kenapa kita dress down seperti ini.

Firman: Tapi ya, Bapak kan Deputy Director, Pak. Kayaknya udah gak level deh untuk Bapak ikut blusukan sama kita. But that's where the action is! And yet that's where you no longer belong, Pak. Dulu saat Bapak masih jadi National sales manager, iya. Tapi Bapak udah DD sekarang, itu gak main-main.

Wati : Canggih juga bahasa Inggris lu, Man. Naksir nih gue, kayaknya rada dikit.

(SBB/PP/116)

Pokok pembicaraan ini terjadi antara Cakra, Firman, dan Wati di sebuah Mall di Jakarta. Pokok pembicaraan yang dibahas adalah mengenai kedudukan Cakra sebagai Deputy Director yang dianggap cara berpakaiannya masih biasa. Wujud alih kode berupa pokok pembicaraan ini dilakukan oleh Firman yang mencoba menjelaskan kedudukan Cakra sebagai Deruktur dalam perusahaanya tersebut. Terlihat dalam tuturan Firman ia beralih bahasa dari bahasa Indonesia ke bahasa Inggris pada tuturan "Tapi ya, Bapak kan Deputy Director, Pak. Kayaknya udah gak level deh untuk Bapak ikut blusukan sama kita. But that's where the action is! And yet that's where you no longer belong, Pak. Dulu saat Bapak masih jadi National sales manager, iya. Tapi Bapak udah DD sekarang, itu gak main-main.”

Tuturan pada awal kalimat Firman "Tapi ya, Bapak kan Deputy Director, Pak. Kayaknya udah gak level deh untuk Bapak ikut blusukan sama kita.” Kemudian beralih bahasa pada tuturan selanjutnya "But that's where the action is! And yet that's where you no longer belong, Pak." yang artinya "Tapi disitulah tempatnya! Namun itu tidak semestinya lagi, Pak." Tuturan tersebut Firman menjelaskan kepada Cakra bahwa Cakra memang sudah tidak pantas lagi untuk ikut blusukan bersama rekannya karena mengingat jabatan Cakra yang dianggap sudah tinggi. 
Topik pembicaraan tersebut yang menjadikan Firman beralih kode dari bahasa Indonesia ke bahasa Inggris.”

\section{Wujud Campur Kode dalam Novel SBB}

Campur kode (Code-mixing) terjadi apabila seorang penutur menggunakan suatu bahasa secara dominan mendukung suatu tuturan disisipi dengan unsur bahasa lainnya.

a. Wujud Campur Kode Berupa Penyisipan Kata

Campur kode berupa sisipan kata ialah berupa unsur bahasa yang dituliskan sebagai perwujudan kesatuan yang digunakan dalam berbahasa.

Setting : Campur kode penyisipan kata ini terjadi antara tokoh Ibu Itje, Satya dan Cakra yang terjadi di dalam rumah Ibu Itje. Mereka adalah satu keluarga.

Ibu Itje: Kalian sedang apa?

Cakra : Ini, kita lagi transfer video Bapak ke dalam hard disk.

Satya : Iya, Mah. Kita bisa kopi semau jadi tiga. Jadi, Mamah pegang satu set kopi, Satya satu dan Saka satu.

(SBB/PKT/ 8)

Wujud campur kode berupa penyisipan kata yang terdapat dalam dialog di atas dilakukan oleh tokoh Cakra. Dialog di atas terjadi di dalam rumah yang dilakukan oleh tokoh Ibu Itje, Satya dan Cakra yang membahas mengenai vidio-vidio peninggalan Bapaknya. Unsur campur kode terlihat dalam dialog Cakra pada tuturan "Ini, kita lagi transfer video Bapak ke dalam hard disk." Dalam tuturan tersebut Cakra disisipi unsur kata "transfer" yang artinya "memindahkan" dan unsur kata "hard disk" yang artinya "perangkat keras." Wujud campur kode yang dilakukan Cakra dengan menyisipi unsur bahasa Inggris di dalam tuturannya karena ungkapan dalam bahasa tersebut tidak ada padanya sehingga menggunakan unsur bahasa lain dalam tuturannya.

b. Wujud Campur Kode Berupa Penyisipan Frasa

Campur kode berupa penyisipan frasa ialah berupa gabungan dua kata atau lebih yang bersifat nonpredikatif.

Setting : Percakapan ini terjadi antara Ibu Itje dan Satya yang terjadi di rumah Ibu Itje. Satya dan Ibu Itje merupakan satu keluarga yaitu Ibu dan anak. 
Ibu Itje: Kakang gak malam mingguan?

Satya : Nggak, Mah.

Ibu Itje: Malam mingguan atuh sanah. Kayak anak teman-teman Mamah yang lain.

$(\mathrm{SBB} / \mathrm{PF} / 7)$

Terdapat wujud campur kode yang dilakukan oleh penutur yakni Ibu Itje dalam tuturannya "Malam mingguan atuh sanah. Kayak anak teman-teman Mamah yang lain." terdapat campur kode dalam bentuk frasa dalam tuturan Ibu Itje berupa "atuh sanah" yang artinya "lah sana". Wujud campur kode tersebut disebut sebagai wujud campur kode berwujud frasa yang berupa gabungan dua kata atau lebih yang bersifat nonpredikatif.

c. Wujud Campur Kode Berupa Pengulangan Kata

Campur kode berupa pengulangan kata ialah sisipan unsur kata yang terdiri dari reduplikasi (pengulangan kata).

Setting : Dialog ini terjadi antara Cakra dan Ibu Itje yang terjadi di dapur rumah Ibu Itje. Cakra dan Ibu Itje adalah satu keluarga.

Cakra : Mamah kayak yang.. agak lambat geraknya.

Ibu Itje: Ya atuh namanya juga udah nini-nini.

Cakra : Kok Mamah pakai jilbab?

Ibu Itje: Bentar lagi mau pergi arisan.

(SBB/PGK/177)

Tuturan antara Cakra dan Ibu Itje di atas membicarakan mengenai kondisi kesehatan jalan Ibu Itje yang sudah mulai lambat. Dalam percakapan tersebut terdapat unsur campur kode yang dilakukan oleh Ibu Itje sebagai mitra tutur. Wujud campur kode tersebut berupa percampuran bahasa Indonesia dengan bahasa Sunda dalam tuturan Ibu Itje "Ya atuh namanya juga udah nini-nini." Turan Ibu Itje tersebut terdapat sisipan unsur kata bahasa Sunda yang berupa kata "atuh" yang artinya "lah" dan kata "nini-nini" yang artinya "nenek-nenek".

d. Wujud Campur Kode Berupa Penyisipan Klausa 
Wujud campur kode berupa klausa yaitu suatu kelompok kata, sekurangkurangnya terdiri atas subjek dan predikat.

Setting : Dialog ini terjadi antara Cakra dan Firman yang terjadi di sebuah mall. Cakra adalah seorang Deputy Director dan Firman adalah seorang seles atau bawahan Cakra.

Cakra : Ada yang salah dengan penampilan gue?

Firman : Well, kalo kalo kita lihat saingan Bapak, Salman, he look like a million dollar man, sedangkan Bapak, you look like you're a million dollars in debt. Untuk posisi setinggi Bapak, Bapak penampilannya terlalu biasa. Gak mencolok.

Cakra : Sebenarnya kalian gak bisa nyalahin penampilan saya. Kalian semua tahu kenapa kita dress down seperti ini.

(SBB/PKL/116)

Cakra dan Firman sedang berada di mall di Jakarta. Tuturan yang terjadi antara penutur Cakra dan mitra tutur Firman ini terdapat campur kode yang dilakukan oleh Firman dalam tuturan "Well, kalo kalo kita lihat saingan Bapak, Salman, he look like a million dollar man, sedangkan Bapak, you look like you're a million dollars in debt. Untuk posisi setinggi Bapak, Bapak penampilannya terlalu biasa. Gak mencolok." Wujud campur kode berupa klausa ini terdapat pada kata "Salman, he look like a million dollar man," yang artinya "Salman, dia terlihat seperti pria jutaan dolar" dan kata "sedangkan Bapak, you look like you're a million dollars in debt" yang artinya "sedangkan Bapak, kamu terlihat seperti jutaan dolar dalam hutang."

\section{Faktor Penyebab Terjadinya Campur Kode dalam Novel SBB.}

a. Identifikasi peranan

Identifikasi peranan yaitu ingin menjelaskan sesuatu atau maksud tertentu dalam sebuah percakapan yang terjadi antara penutur dan mitra tutur.

Setting : Percakapan ini dilaukan oleh tokoh Cakra dan Krisna yang terjadi di ruang kerja Cakra.

Cakra : Bagus deh ini form-nya. Kalo boleh saya tahu, apa yang kamu pelajari dari magang di sini? 
Krisna : Saya melihat bahwa dunia kerja itu beda dengan dunia akademis. Dunia akademis itu mementingkan prestasi. Taoi dunia kerja itu menentingkan soft skill. Benar kan Pak?

Cakra : Soft skill seperti?

Krisna : Ya, yang seperti Bapak miliki. Saya melihat Bapak itu dekat dengan bawahan-bawahan dan dengan dekat saya melihat mereka lebih mengerti perintah-perintah Bapak dan menjalankanya. Itu soft skill yang penting Pak, itu semua yang membawa karier maju bukan karena pintar. Pintar belum tentu sukses. Lihat Bill Gates kuliah aja DO tapi jadi juga.

$(\mathrm{SBB} / \mathrm{IP} / 48)$

Percakapan antara Cakra dan Krisna di atas merupakan contoh campur kode yang termasuk dalam faktor berupa identifikasi peranan ingin menjelaskan suatu maksud tertentu. Terlihat dari tuturan Krisna dalam tuturan "Saya melihat bahwa dunia kerja itu beda dengan dunia akademis. Dunia akademis itu mementingkan prestasi. Tapi dunia kerja itu menentingkan soft skill. Benar kan Pak?”. Jawaban Krisna tersebut merupakan bentuk identifikasi peranan yang ingin menjelaskan sesuatu pada Cakra dengan mensisipkan usur bahasa lain sebagai wujud campur kode dalam tuturannya. Hal itulah yang dinamakan faktor campur kode dalam bentuk identifikasi peranan.

b. Identifikasi ragam

Identifikasi ragam yaitu situasi yang ditentukan oleh bahasa di mana seorang penutur melakukan campur kode dan menempatkan dirinya dalam hierarki status sosialnya.

Setting : Percakapan ini terjadi dalam dialog antara Firman, Cakra, Wati dan Bambang yang terjadi di sebuah mall.

Firman : Ya kalo mau perbaikan penampilan, ya pakek yang mahal.

Cakra : You know what kalian bertiga duduk aja. Gue milih sediri. Gue cuma mau beli yang gue suka, mahal atau murah.

Wati : Jauh lebih baik.

Bambang : Tapi jujur ya, gak terlihat apa ya gak terlihat semahal Salman, gitu.

(SBB/ IR/118)

Faktor identifikasi ragam ini dilakukan seseorang untuk menempatkan dirinya dalam hierarki status sosialnya. Identifikasi ragam tersebut terdapat dalam dilaog 
yang terjadi antara Firman, Cakra, Wati, dan Bambang yang terjadi di sebauh mall di Jakarta. Faktor campur kode berupa identifikasi ragam ini terjadi dalam tuturan Cakra pada tuturan "You know what kalian bertiga duduk aja. Gue milih sediri. Gue cuma mau beli yang gue suka, mahal atau murah.” Tuturan Cakra tersebut menjelaskan bahwa ia akan memilih pakaian yang ia suka tidak melihat dengan mahal atau murahnya harga yang akan dibeli.

c. Keinginan untuk menjelaskan dan menafsirkan.

Keinginan untuk menjelaskan dan menafsirkan yaitu ingin menjalin keakraban antara penutur dan lawan tutur dalam menandai sikap dan hubungannya pada saat berhubungan atau berkomunikasi dengan orang lain.

Setting : Percakapan antara Cakra dan Ayu yang terjadi di ruang kantor.

Cakra : Gimana? lancar kerjanya?

Ayu : Lumayan gak jauh beda sama bank sebelumnya.

Cakra : Bagus kalau begitu. Anak-anak micro finance sering ngerecokin customer service kalo mereka bawel, let me know, yah.

Ayu : Hhaha, $O k$, Mas!

(SBB/ KUM/96)

Tuturan antara Cakra dan Ayu ini merupakan contoh dialog yang termasuk dalam bentuk faktor untuk menjelaskan yang terdapat dalam tuturan Cakra "Bagus kalau begitu. Anak-anak micro finance sering ngerecokin customer service kalo mereka bawel, let me know, yah.”. Tuturan Cakra tersebut termasuk dalam faktor keinginan menjelaskan bahwa teman-teman di kantornya sering ngerecokin Ayu. Keinginan untuk menjelaskan tersebut juga termasuk sikap yang ditunjukkan Cakra untuk menunjukkan hubungan keakraban yang dijalin dengan Ayu. 


\section{PENUTUP}

Berdasarkan hasil penelitian dapat disimpulkan bahwa terdapat wujud alih kode internal berupa alih bahasa yang meliputi: a) Alih bahasa Sunda ke bahasa Indonesia, dan b) Alih bahasa Indonesia ke bahasa Jawa. Wujud alih kode eksternal berupa alih bahasa yang meliputi: a) Alih bahasa Indonesia ke bahasa Inggris, dan b) Alih bahasa Inggris ke bahasa Indonesia. Terdapat faktor penyebab terjadinya alih kode dalam novel SBB yang disebabkan adanya pembicara atau penutur, lawan tutur atau pendengar, perubahan topik pembicaraan dan pokok pembicaraan.

Wujud campur kode yang terdapat dalam novel SBB meliputi : a) Campur kode berupa penyisipan kata, b) Campur kode berupa penyisipan frasa, c) Campur kode berupa pengulangan kata, dan d) Campur kode berupa penyisipan klausa. Campur kode yang terdapat dalam novel SBB tidak terjadi begitu saja melainkan terdapat faktor yang memengaruhi terjadinya campur kode tersebut. Faktor yang menyebabkan terjadinya campur kode dalam novel $S B B$ disebabkan adanya identifikasi peranan, identifikasi ragam, dan keinginan untuk menjelaskan atau menafsirkan sesuatu.

\section{DAFTAR RUJUKAN}

Aslinda dan Syafyahya Leni. 2007. Pengantar Sosiolinguistik. Bandung: PT Refika Aditama.

Kridalaksana, Harimurti. 2010. Kamus Linguistik. Jakarta : PT Gramedia Pustaka Utama.

Mahsun. 2006. Metode Penelitian Bahasa. Jakarta: PT Raja Grafindo Persada.

Sugiyono. 2014. Metode Penelitian Kuantitaif Kualitatif dan $R \&$ D. Bandung: Alfabeta, cv. 